\title{
Proximate Composition And Consumers Acceptability Of Bread Produced From Blends Of Soy-Cheese And Wheat Flour.
}

\author{
${ }^{1}$ Odedeji J. O., ${ }^{1}$ Ojo, A., ${ }^{1}$ Arogundade, L. A. and ${ }^{2}$ Oyeleke, G. O. \\ ${ }^{I}$ Department of Food Science and Technology, Osun State Polytechnic, Iree, Nigeria. \\ ${ }^{2}$ Department of Science Laboratory Technology, Osun State Polytechnic, Iree, Nigeria.
}

\begin{abstract}
Work on effect of soy-cheese flour inclusion in bread production was investigated. Soy-cheese was produced from carefully sorted and cleaned soybeans and later processed into flour through drying, milling and sifting operations. Bread samples were thereafter produced from blend of wheat and soy-cheese flour using the following blend ratios: 95:5, 90:10, 85:15, 80:20. Bread sample was equally produced from 100\% wheat flour which served as control. The bread samples were subjected to proximate and organoleptic analysis. The results of proximate analysis revealed that fortified bread samples had higher proximate constituents than the control with the exception of carbohydrate content. The organoleptic analysis result revealed that there was no significant difference among the samples and control in terms of crust and crumb color, taste, flavour, and overall acceptability. However there was significance difference among the samples in term of texture. Acceptable bread samples could therefore be produced from blends of wheat and soy-cheese flour with improved proximate and organoleptic qualities.
\end{abstract}

Keywords: Soy-cheese, proximate, organoleptic, crust, crumb.

\section{Introduction}

Bread belongs to the class of a ready to eat food made by mixing wheat flour with water and yeast, kneading and baking in an oven. Bread is convenient as a food because it is a ready to eat, easily carried around, and not messy to eat. Its taste is highly acceptable, it gives feeling of bulk and fullness when eaten, and is considered relatively cheap [1,2].

Wheat flour, the major ingredient of bread production is made from wheat, a cereal, which has a unique characteristic to hold or retain gas in form of air, water vapour and carbon dioxide thereby capable of forming foam or a spongy structure while other cereals such as maize, sorghum, millet, rice etc do not possess this unique quality. Though wheat is a temperate crop yet cereals grains cannot be discussed in Africa without a mention being made of the increasing demands made on wheat flour in Africa, where the population is being fed on food the country does not grow. Their scarce foreign exchange is being used to import wheat as well as machines spares and foreign management to maintain and run the flour mill [3]. In order to reduce high foreign exchange on wheat importation and flour mills, a lot of research works have been made by various researcher $[3,4,5]$ to produce composite bread i.e. bread made with wheat and non-wheat flours such as maize, millet., rice flour etc. These non-wheat flours and starches are lower in protein and higher in carbohydrate than wheat flour. When non-wheat flours are mixed with wheat flour, the protein content of the resulting mixture is greatly impaired. The resulting low protein content of the mixture (dough) weakens the dough structure by diluting the wheat protein-gluten which is a major factor necessary for dough development and formation. Under this condition the bread loaf is badly formed with poor crumb structure and poor nutritive values.

White bread according to Whitaker [6] was listed among the foods such as sugar, white rice, white flour that he described as simple carbohydrate foods which are like fillers that take up space in our stomach which should have been reserved for complex carbohydrate foods such as unprocessed grains, starches and vegetables which are more nutritious. When one eat refined carbohydrates with a high sugar content it tends to decrease the amount of vitamins and minerals in the system particularly the B-complex vitamins, it also added extra unneeded pounds and increase cholesterol and triglyceride levels in our body system [6].

In order to improve the nutritive content of white bread and prevents the preventable diseases and ailments associated with it, efforts have been made to fortify bread flour with groundnut flour, soy flour, melon seed flour, cowpea flour etc. These nuts and legumes flour contain a lot of protein and other food nutrients that might have been lost during wheat processing into flour [7].

However, little information is found in literature with regard to the effect of milk powder or concentrated protein on the loaf quality and its consumer acceptability. The aim of this research work therefore, is to fortify wheat flour with soy-cheese flour at different proportion to produce composite bread samples and carry out proximate analysis as well as establishing consumers' acceptability of the bread samples. 


\subsection{Materials}

\section{Materials and Methods}

Wheat flour and soya beans were purchased at Oluode market, while other materials such as granulated sugar, yeast, butter, salt etc where bought at Orisunmbare market both at Osogbo, Osun State, Nigeria.

\subsection{Methods}

\subsubsection{Production of Soy-cheese flour}

Soybeans were soaked in boiled water for 1 hour, dehulled and mechanically milled into a paste. The paste was sieved through a $500 \mu \mathrm{m}$ mesh size, $2 \%$ lime was added and cooked to coagulate protein. The coagulated protein was pulverized and dried in hot air oven (MIDO/2/SSIF) at $60^{\circ} \mathrm{C}$ for 24 hours. The dried cheese was milled with attrition mill (model: 3705) and sieved through a 500 $\mu \mathrm{m}$ mesh size sieve. The flour was packed in a close container and kept in a cool and dry place at room temperature until needed for further analytical work.

\section{Table 1:}

\subsubsection{Production of Bread-Fortified with Soy-Cheese Flour}

\begin{tabular}{|c|l|l|}
\hline Sample codes & \multicolumn{2}{|c|}{ Composition } \\
\hline & WF\%: & SCF\% \\
\hline X & $100: 0$ \\
A & $95: 5$ \\
B & $90: 10$ \\
C & $85: 15$ \\
D & 80 & $: 20$ \\
\hline
\end{tabular}

Flour samples were measured in ratio 95:5, 90:10, 85:15 and 80:20\% of wheat flour and soy-cheese flour to produce four different samples tagged samples A, B, C \& D respectively while $100 \%$ flour sample is the control and tagged sample $\mathrm{X}$.

\subsubsection{Bread Production}

Flour and all other ingredients were weighed accordingly and mechanically mixed to form dough. The dough was allowed to ferment for two and a half hours ( $2 \frac{1}{2}$ hours). At the end of this period, the fermented dough was cut up with knife, remixed mechanically again for five minutes (5minutes) and then allowed to ferment for another one and a half hours ( $1 \frac{1}{2}$ hours). The dough was cut into weighed pieces, rolled into ball, and subsequently moulded into sausage - shaped pieces which were dropped into individual baking pan. Proofing was done at $38^{\circ} \mathrm{C}$ for 45 minutes and baked in an oven at $220^{\circ} \mathrm{C}$ for 45 minutes. The baked products were allowed to cool, packaged and stored in a cool and dry place.

\subsubsection{Proximate Analysis of Bread Fortify with Soy-Cheese Flour.}

Proximate composition in terms of carbohydrate, protein, fat, ash, crude fibre and moisture content were determined according to AOAC, [8] methods.

\subsubsection{Organoleptic Analysis.}

Randomly selected 10 panelists from staff and students of Food Science and Technologist Department of Osun State Polytechnic, Iree, were engaged to organoleptically assess the bread samples for crust and crumb colours, taste, flavour, texture and overall acceptability using a nine point hedonic scale. All data generated were in triplicate and the mean values calculated. The mean values were subjected to analysis of variance (ANOVA) and separated by Duncan Multiple Range Test (DMRT) [9]. 


\section{Results and Discussion}

\subsection{Proximate Analysis Results of the Bread Samples}

The result of proximate analysis of bread samples fortified with Soy-cheese flour is as shown in Table 2 below.

\begin{tabular}{|c|c|c|c|c|c|c|c|}
\hline \multirow{2}{*}{ Samples } & \multicolumn{9}{|c|}{ Parameters \% } \\
\cline { 2 - 8 } & Moisture \% & Protein & Fat & Ash & Crude fibre & Carbohydrate & Dry matter \\
\hline A & 10.32 & 9.40 & 15.96 & 4.00 & 0.0 & 60.32 & 81.68 \\
\hline B & 11.09 & 10.12 & 16.20 & 3.00 & 0.0 & 59.59 & 83.91 \\
\hline C & 11.22 & 12.48 & 16.95 & 3.00 & 0.0 & 56.38 & 81.78 \\
\hline D & 11.60 & 14.15 & 17.45 & 3.00 & 0.0 & 47.80 & 82.37 \\
\hline X & 12.15 & 6.04 & 14.90 & 3.00 & 1.00 & 62.91 & 73.25 \\
\hline
\end{tabular}

From the table, moisture content of fortified bread samples ranged between $10.32-11.60 \%$. Sample D had the highest value (11.60\%) while sample A had the least value (10.32\%), these values were lower than $12.15 \%$ recorded by the control sample (Sample X). The relatively low moisture content observed in fortified bread samples might be due to incorporation of soy-cheese flour. Bread, an intermediate moisture food (IMF) contains moisture low enough to prevent the growth of any organisms except mould which can also be prevented when store under low humid conditions. Therefore, the lower moisture content observed in fortified bread samples will promote its longer shelf life than conventional bread when stored under the same conditions. In term of protein, fortified bread samples recorded higher values than the control sample. It is observed that protein content of each bread sample increased with an increase in soy-cheese flour ratio. This infers that Soycheese is a good precursor of protein which serves as a primary source of amino acid, the building block of body cells. It also act as antibodies and repair damage cells. Therefore inclusion of Cheese flour with wheat flour improves the nutritional qualities of bread. Sample D (20\% cheese flour) recorded the highest value of $17.45 \%$ and sample A (5\% soy-cheese flour) recorded $15.96 \%$ while the control sample (whole wheat flour) recorded the least value of $14.90 \%$. Fat was also found to be on the increase as soy cheese flour ratio increases. Values obtained ranged between $15.96-17.45 \%$ while the control sample recorded $14.90 \%$.

Sample D recorded the highest value $17.45 \%$ while sample A recorded the least value of $15.96 \%$. The higher fat content recorded in fortified bread samples will improve its nutritional content especially the fat soluble vitamins and enhance the textural qualities of the samples. The ash content of fortified bread samples and control sample were relatively equal. As ash content gives an insight to the mineral content of the food hence, Soy-cheese and wheat flour can be described as a poor source of minerals hence the relatively low-value recorded in both the samples as well as control. In term of crude fibre, fortified bread samples recorded $0.0 \%$ while control sample recorded $1.0 \%$. Processing of wheat and soya beans into flour which involves the unit operations of milling and sieving among others, have removed substantially their fibre content, hence fine particulate flour samples were obtained. This inferred that the bread (control) and fortified bread samples are not a good source of fibre in our diet and eating bread all alone may hinder peristalsis movement of food through the digestive tract and prevent food digestion. The carbohydrate content of fortified bread samples ranged between $47.80-60.32 \%$. It was observed that carbohydrate value of the samples decreases with an increase in soy-cheese flour ratio. Sample A (with 5\% soy-cheese flour) recorded the highest value of $60.32 \%$ while sample D (with $20 \%$ soy- cheese flour) recorded the least of $47.80 \%$. Therefore, bread can be described as a carbohydrate food that can serve as a good source of energy for human nutrition. Also all the fortified bread samples recorded higher values for dry matter than the control sample. The values obtained ranged between $83.91-81.68 \%$ for samples while the control sample recorded.

Therefore, fortification of wheat flour with soy cheese flour will produce bread that is more nutritious, more nourishing and well acceptable product.

\subsection{Results of Organoleptic Analysis of the Bread Samples}

\section{Table 3: Sensory Evaluation of Fortified Bread with Soy-cheese Flour}

The result of organoleptic analysis of bread samples fortified with soy cheese flour is as shown in Table 3 below.

\begin{tabular}{|l|c|c|}
\hline \multirow{2}{*}{ Parameters } & \multicolumn{2}{|c|}{ Q. FACTORS } \\
\cline { 2 - 3 } & F $_{\text {tab }}$ & F $_{\text {cal }}$ \\
\hline Crust \& Crumb colour & 3.13 & 2.60 \\
\hline Texture & 3.01 & 3.78 \\
\hline Taste & 2.99 & 1.20 \\
\hline Flavour & 3.24 & 1.60 \\
\hline Overall acceptability & 3.05 & 2.65 \\
\hline
\end{tabular}


From the table, the $\mathrm{Q}$ factor $\left(\mathrm{F}_{\mathrm{cal}}\right)$ for crust and crumb, colour, taste, flavour and overall acceptability were greater than the $\mathrm{Q}$ factor $\left(\mathrm{F}_{\mathrm{tab}}\right)$ therefore there is no significant different at $5 \%$ confidence limit among the samples in all parameters listed above. But under texture the $\mathrm{Q}$ factor $\mathrm{F}_{\mathrm{cal}}$ is greater than the $\mathrm{Q}$ factor $\left(\mathrm{F}_{\mathrm{tab}}\right)$ therefore; there is a significant difference among the samples in term of texture at $5 \%$ confidence limit.

Ayenor, [10] and Otegbayo et al., [11] reported that a defect in the perceived texture of the food would have an extreme negative impact on the consumers' hedonic response to the food. Therefore, the significant difference observed in texture of fortified bread sample is suspected to result from soy-cheese flour inclusion which reduces the overall gluten content of wheat flour because as soy-cheese flour ratio increases the gluten content in wheat flour is undergoing dilution hence there is reduction in the dough rising capacity during proofing which resulted in relatively hard texture. However, incorporation of soy-cheese flour up to $15 \%$ produces a good quality bread and acceptable product.

\section{Conclusion}

It is observed that all fortified bread samples were rated higher in terms of nutritional composition and consumers acceptability than the reference sample, therefore it can be concluded that fortification of wheat flour with soy-cheese flour will produce a composite bread of a longer shelf life, more nourishing and a well acceptable product. It will also go a long way in solving the problems of malnutrition ravaging most developing countries including Nigeria.

\section{References}

[1] Casier, J.P.J., De Paepe, G.M.J., Williams, H.E.J., Goffings, G.J.G., Hermans, J.L. and Noppen, H.E., Bread Production from Pure Flours of Tropical Starchy Crops: III from Pure and Mixed Flours of Cassava, Millet, Sorghum, Corn, Rice and Starches, Tropical Foods, Vol. 1 (1979): 279 - 339, Academic Press Inc.

[2] Adeleke R.O., and Odedeji, J.O., Acceptability Studies of Bread Fortified with Tilapia Fish Flour, Pakistan Journal of Nutrition. 9 (6) (2010): $531-534$

[3] Hart, M.R. Graham, R.P., Gee, M., and Morgan Jr. A.I. (1970). Bread from Sorghum and Barley Flours, Journal of Food Science. Vol. 35 (1970): 661-665.

[4] Kim, J.C., and de Ruiter, D., 'Bread from Non-wheat Flours', Food Technology Vol. 22 (1967): 867 - 878

[5] Odedeji, J.O. and Odetayo, T.A., Bread Production Cost Reduction through the Inclusion of Soy bean Flour. Journal of Arts \& Social Science 1:1 (2010): 49 - 58.

[6] Whitaker, D., Carbohydrates in Feel Better Live Longer. Frontline publication, SJBS Outreach, Lagos Nigeria (2008): 61-62.

[7] FAO/WHO, Tubers, Cereals, Grain Legumes and their Products, Production, Consumption, Trade and Legislation in African Countries; Codex Alimentarius Commission Co-coordinating Committee for Africa, (1997). Third Session - Ghana.

[8] A.O.A.C., Official Methods of Analysis $16^{\text {th }}$ edition Association of Official Analytical Chemists. (1990), Arlington, Virginia.

[9] Akinjayeju, O., Organoleptic Assessment of Foods. In Statistical Quality Control. Concept Publications Limited Lagos. Nigeria. (2002): $151-188$.

[10] Ayenor, G. S., The Yam Starches. In: Advances in Yam Research, (ed. Osuyi G.) (1985): 77-78. Biochemical Society of Nigeria, Anambra State University of Technology, Enugu - Nigeria.

[11] Otegbayo, B., Aina, J., Sakwi - Dawson, E., Bokanga, M. and Asiedu, R., Sensory Texture Profiling and Development of Standard Rating Scales for Pounded Yam. Journal Texture Studies 36 (2005): 476 - 488.

[12] Tsen, C.C., 'Using Non-wheat flours and Starches from Tropical Crops as Bread Supplements', Tropical Foods, Vol., 1 (1979):239-247, Academic Press Inc. 